\title{
Concepts and Facts of Late Ottoman Jaffa: Cartographic Records and Archaeological Evidence
}

\author{
Yoav Arbel ${ }^{\mathrm{a} *}$, Baruch Rosen $^{\mathrm{b}}$ \\ ${ }^{\mathrm{a}}$ Israel Antiquities Authority - yoar07@gmail.com, ${ }^{\mathrm{b}}$ Independent researcher - rosenbar@,netvision.net.il \\ * Corresponding author
}

\begin{abstract}
The ancient city of Jaffa experienced considerable changes during the 19th century. The effects of warfare, extensive reconstruction and urban expansion turned the Jaffa of 1900 into a markedly different place than the town Napoleon besieged in 1799. Although textual, artistic and photographic records reflect these long-term changes, it is maps drawn by military and civilian European engineers that provide the most comprehensive illustrative testimony.

Recent archaeological efforts have, moreover, added yet another perspective to this mosaic of sources. Among the material evidence providing valuable insight into Jaffa's 4000 years of history, data on the later phases of Ottoman rule is particularly intriguing. We now have previously unavailable material confirmation and more detailed records in a higher resolution for urban expansion over farmland and cemeteries, road paving, public construction and the dismantling of fortifications.

The joint cartographic and archaeological testimonies offer a more realistic outlook on a period, which, until recently, had been subjectively perceived through military and religious filters, or the critical and often derogatory perspectives of explorers, adventurers and tourists. The challenges the Ottoman authorities faced were numerous and complex; cartographic and archaeological evidence has increased our understanding of the means, investment and planning they employed to maintain control over a thriving and heterogeneous harbor town during a period of profound transformation.
\end{abstract}

Keywords: Ottoman, Jaffa, Maps, Archaeology, Ramparts, Urban

\section{Introduction}

William Wittman, a member of the British Military Mission assisting the Ottomans against Napoleon, was unimpressed by what he had seen during a visit to Jaffa in 1799. The city's streets, Witttman stated, were "very narrow, uneven and dirty" and "rather entitled to the appellation of alleys". Regarding the local homes, "on the score of filth, as well as of waste of space many of them are little better than pig-sties" (Wittman 1803:129130). Six decades later Murray's travel handbook (Murray 1858:272) gives us a fairly similar testimony: "The houses are huddled together without regard for appearance or convenience; the streets form a labyrinth of blind alleys and narrow, crooked, filthy lanes; and the whole town is so crowded along the steep sides of the hill that the rickety mansions on the upper part seem to be toppling over the roofs of those below them." Numerous 19th century European visitors echoed the sentiment. Cultural gaps between Europe and the Levant, the disappointment of harsh realities in fabled biblical locations, and bewilderment in radically alien scenes all surely influenced the accounts, yet given the volume of similar testimonies there can be little doubt that the descriptions, even when exaggerated for effect, generally reflect the sights and state of 19th century Jaffa. By the 1880 s, nonetheless, a new situation was taking shape at Jaffa's formerly unsettled outskirts, where, it was said, "each day, new buildings multiply" (Brill 1883:196, cited in Kark 1990:101). Other testimonies, painted panoramas and early photographs support this account.

Written and pictorial representations, enlightening as they may be, share an unavoidable subjectivity; they are the products of specific perspectives influenced by personal inclinations. Cartography and archaeology cannot claim pure objectivity any more than other human endeavors but at least in principle, they are less open to personal impressions. Cartographers are charged with creating a dependable orientation tool for individuals and entities with vested political, commercial, religious, scholarly or military interests. Practical, concise and up-to-date information on features, proportions and routes is required, and the final product is evaluated primarily according to its accuracy and reliability. Earlier cartography, while also fundamentally committed to providing solid information, sometimes added bright color, fine calligraphy and touches of art. The more recent the maps, the less these embellishments are featured.

Archaeology, like cartography, cannot afford the measure of manipulation for the sake of aesthetics, perspective and religious commitment that texts and illustrations may sometimes be allowed. Archaeologists are expected to produce professional research articles in their fields of study, and when reporting a site, they are compelled to provide a robust and steadfast record of the full architectural and artefactual assemblages exposed. The privilege to focus on phases and types of finds of particular interest is reserved for their readers. Field 
researchers are well-acquainted with the dissonance between the excitement of discovery and the restraint that must be implemented in reporting, where providing distilled and factual data is the base rule.

In past papers, I combined historical records and archaeological remains to investigate the profound urban changes Jaffa had experienced from 1799 to the British conquest in 1917 (Arbel 2014; 2017a). Maps, which were used there as secondary tools, are at the core of the present paper, along with related archaeological discoveries. Architectural remains associated with features in four maps drawn between 1799 and 1878 will be discussed. In essence, this is a first attempt to illustrate the potential and advantages of an interdisciplinary cartographic-archaeological approach to the research of late Ottoman Jaffa.

\section{Historical background}

\section{Jaffa until 1800.}

Exceptionally fertile soil, plenty of fresh water and a strategic location on land and sea routes have kept Jaffa settled almost continuously since the early second millennium BCE (Kaplan 1972:75). Many powers coveted the town. Canaanite, Egyptian, Phoenician, Hellenistic, Hasmonean, Roman, Byzantine, Arab, Crusader, Mamluk, Ottoman and British standards all flew from its masts before the Israeli flags of the present.
The material marks of these occupiers are embedded in Jaffa's soil.

Political and economic fluctuations dictated the dimensions of the urban sphere. While Jaffa's mound was never completely abandoned, urban spread into the surrounding lower grounds to the north, south and east was only viable in periods of security and prosperity. Such was the case under Hellenistic, Byzantine, early Islamic and Crusader rule. In other periods, as archaeological research evinces, the lower grounds housed farms, agricultural plots and graveyards (Arbel 2017b).

In 1265, Mamluk forces expelled the Crusaders from Jaffa for the last time. Along with all other coastal cities of the Holy Land, Jaffa underwent systematic destruction in the course of the Mamluk strategy of depriving future Crusader expeditions of landing spots along the coast. In the following centuries, numerous testimonies described European pilgrims and traders being forced to disembark in the poorly maintained anchorage, and suffering hardship and humiliation from Mamluk and Ottoman guards (Tolkowsky 1924:129135). Impressionistic illustrations made by eyewitnesses or based upon their experiences are the only visual testimonies to this difficult, centuries-long situation (Figure 1). Reconstruction began only in the mid-17th century (Tolkowsky 1924:135-139; Glick, Stone and Terian 2014). By the end of the 18th century, Jaffa was a small walled town of a few thousand

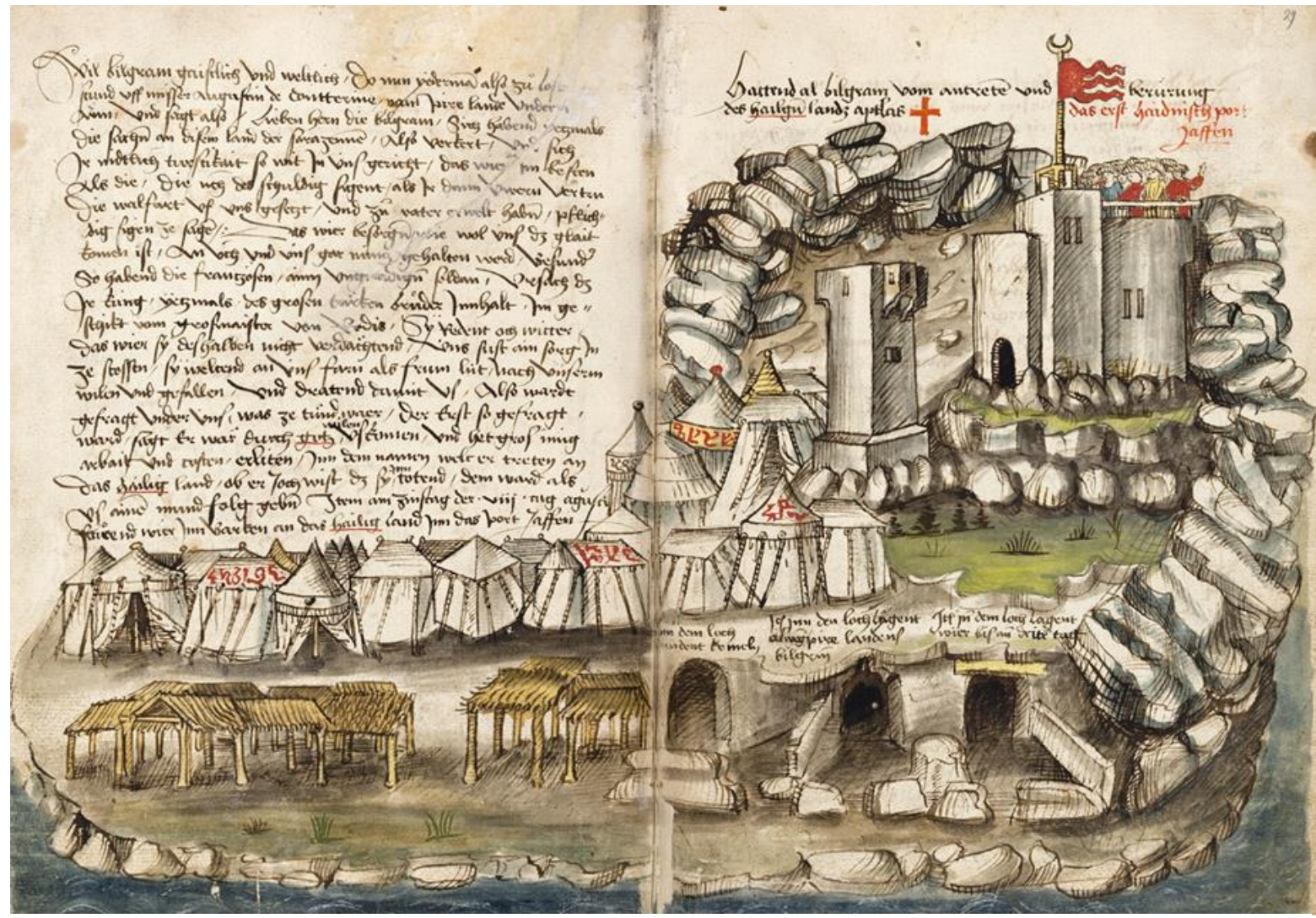

Figure 1. A scene of Jaffa in 1487, showing the vaults and huts in which arriving travellers had to stay and the Mamluk guard towers atop the derelict city. Source: "File: Konrad von Grünenberg - Beschreibung der Reise von Konstanz nach Jerusalem - Blatt 28v-29r.jpg," Wikimedia Commons, the free media repository. 


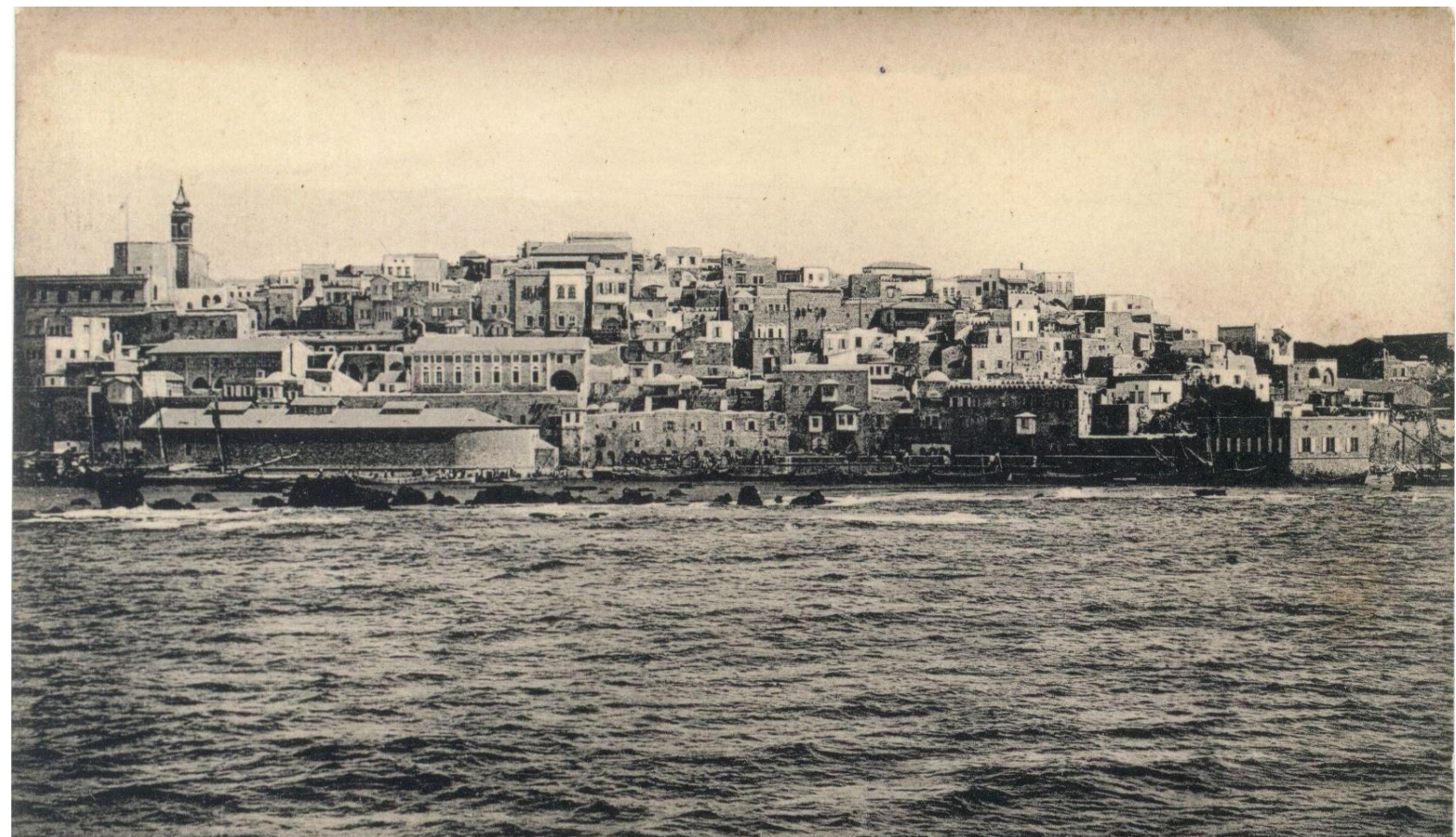

Figure 2. Jaffa from the sea in the 1890s. To the left are the Ottoman customs house and the Greek convent. The infamous sea ledges are seen in the forefront. T. Shacham collection

residents, yet significant enough to be fought over and besieged by regional strongmen, and in 1799 by Napoleon Bonaparte.

\section{Jaffa between 1800 and 1917.}

Napoleon's withdrawal in May of 1799 made the French occupation one of the briefest in the city's history, but its direct and indirect consequences could be felt decades later. Conflicts between Ottoman officers subjected the battered city to additional siege episodes until Muhammad Aga Pasha, known as 'Abu Nabbut' ("father of the cudgel") seized control on behalf of the sultan and stabilized the situation. Large-scale reconstruction was carried out under his strict and effective rule (1804-1819), complementing earlier British efforts. Jaffa's fortifications were restored, a central mosque was constructed, and other public complexes such as covered markets and public baths were erected (Kark 2011:131-132; Kana'an 2001a). Significant political and social changes took place between 1831 and 1840, when the Egyptian armies of Muhammad 'Ali and his son Ibrahim Pasha Jaffa occupied the city. The reforms the Egyptians enforced, inspired to an extent by methods and ideas Napoleon had introduced to Egypt, altered centuries-old conditions in their domains. Among the lasting consequences was an increase in European involvement in local affairs through their consulates, and the mass settling of Egyptian peasants in villages established around Jaffa (Kark 1990:56; Blumberg 2007:151-162). The imprint of these reforms outlived the ousting of the Egyptian armies in 1840, as the reestablished Ottoman government upheld many of the Egyptian policies.

Jaffa, now politically stable and militarily secure, began spreading beyond the traditional boundaries of the mound. The city walls, which no longer served their purpose, were pulled apart during the 1870 s and 1880 s. Hotels and pilgrims' hostels were built along the main routes linking Jaffa to other coastal cities and the hinterland. Modern schools, hospitals and postal agencies were established under European sponsorship. New streets were lined with shops selling imported commodities, and international travel agencies and shipping companies opened offices there.

The port, while still mostly a narrow strip along the coast with rock ledges forcing ships to anchor a mile away (Figure 2), enjoyed a boost of activity, serving commerce, pilgrimage and tourism (Haddad 2013:9498; Mirkin 2017:141-145). Prosperity attracted new settlers and additional extra-mound construction to the north, south and east of the city. Much of the building activity came at the expense of Jaffa's rich agricultural belt, and farming lost its prominence in the city's economy to fast-growing commerce and industry. The ANZAC troops of the British army, which took Jaffa unopposed in November 1917, stepped into an ancient place that had survived violence, destruction, instability and epidemics over the previous fifteen decades, yet had grown and prospered nonetheless. The traumatized, half-ruined Jaffa that Napoleon had left behind had turned into a thriving urban center, home to a heterogeneous population of 20,000 souls (Kark 1990:145-151). Architectural evidence of this transformation can still be seen in the present streets of Jaffa, and in the foundations of derelict structures that lie underground, along with a plethora of telltale artifacts. 


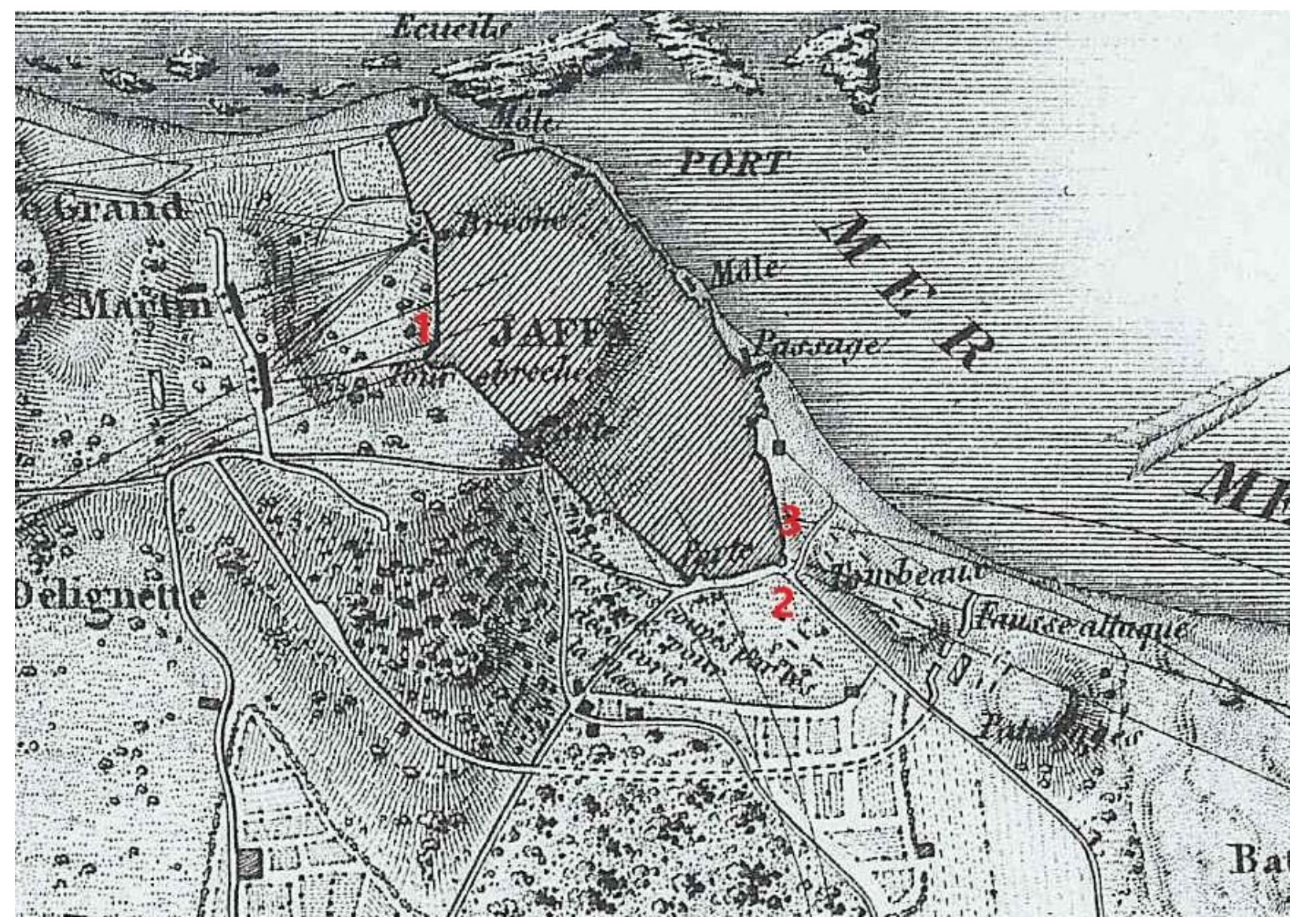

Figure 3. Jaffa in 1799, with locations of archaeological remains. Source: Dénain 1830-36.

\section{Maps and Material: Archaeological remains pertaining to the cartographic records}

\section{The walls Napoleon stormed}

The Jacotain Maps. Engineers serving with Napoleon's Syrian expedition under Colonel Pierre Jacotain are responsible for the first reliable maps of Jaffa, its seafront and environs. A pencil-drawn map and a bathymetric draft of the harbor and its ledges were the base for three other maps. Colors on two of the maps enhance topographic details, the surrounding orchards and the seasonal swamp (el-Bassa), to the northeast of the city (Shacham 2011:137-138; figs. 13.4-5, 13.710). One of these two maps includes a drawing of the southern battlements of Jaffa. A gap in the wall and a pile of debris mark the breaching point into the city. A fourth map is dedicated to the general region of Jaffa, and shows field tracks and agricultural plots (Shacham 2011, fig. 13.2) (Figure 3). It should be stressed that the men who prepared these maps were mostly interested in the military aspects of Jaffa. Thus, the ramparts and bathymetric features of the seafront are depicted in detail, and the citadel (Chateau) is the only building marked within the city itself (on one of the maps). Still, the depictions of the orchards, the swamp and the northern Muslim cemetery provide valuable data on Jaffa's surroundings at that time. The Jacotain maps are in fact the first European source to relate of that cemetery, which would continue to serve Jaffa's Muslim population into the first two decades of the 20th century (Arbel 2017c:103-107).

Archaeological evidence. Count Constantine de Volney, who visited Jaffa in 1783, wrote that the city walls were "twelve to fourteen feet high and two or three in thickness", and unflatteringly likened them to "a common garden wall" (Volney 1788:136-137). Yet these walls, in restored form after Jaffa's destructive conquest in 1776 by the Egyptian forces of Muhammad Abu-Dahab, withstood Napoleon's bombardment longer than the French general had anticipated. Remains of Jaffa's fortifications from the end of the 18th century came to light in excavations at the sites of the St Louis Hospital, the Ottoman military compound and Ruslan Street (Figure 3.1-3 respectively).

The St Louis hospital was one of the institutions inaugurated in Jaffa under French sponsorship during the late 19th century. Completed in 1879 and operated by nuns of the Order of St. Joseph of the Revelation, it stands at the location of the large southeastern bastion of the Ottoman ramparts. Excavations in 2007 (Re'em 2010) revealed a section of a stone wall $15 \mathrm{~m}$ long, 2.2 $\mathrm{m}$ wide and up to $2 \mathrm{~m}$ in surviving height, that was part of the 18 th century fortifications. The remains were set over relief arches, a common construction method of the late Ottoman period in Jaffa. Another structure ascribed to the same phase was a solid tower, which incorporated the remains of a Crusader tower or gate. Preserved to a maximum height of $5.5 \mathrm{~m}$, it was a square building with 


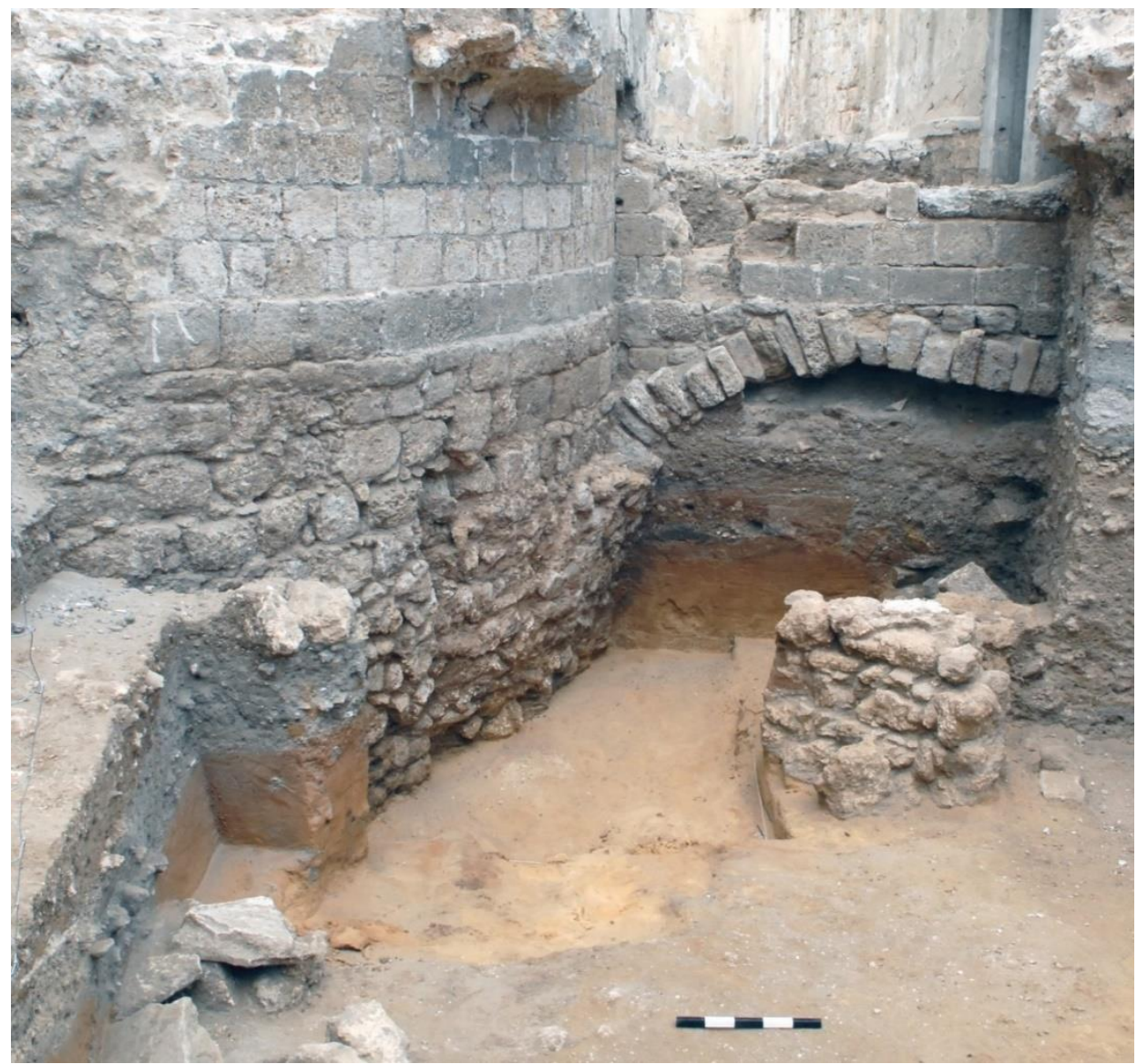

Figure 4. The 18th century semicircular tower and wall segment exposed at the Ottoman military compound. Photograph by T. Sagiv, Israel Antiquities Authority.

rounded corners, of which three sides were exposed. The tower was built over relief arches, like its associated wall segment. This southeastern tower was one of three originally assigned targets of Napoleon's artillery, but withstood the battering and was only destroyed after the conquest. On one of the Jacotain maps it is described as Tour ébréchée (cracked tower). During the 1880 s, a new military compound was constructed on the grounds of the derelict northeastern tower of Jaffa's ramparts (Shacham, in press). It later served as local headquarters for the British Mandate and Israeli police forces, and has recently been refurbished as a hotel. Large-scale excavations at the compound in 2007 (Arbel, in press) revealed parts of Jaffa's fortifications from the 18th and 19th centuries.

The 18th century remains comprise a segment of a wall and a semicircular tower joined by interlocking stones (Figure 4). Only three stone courses of the superstructure survived. They were set on asymmetrical relief arches, some broad and squat and others taller and narrower. The overall surviving height of the tower reaches ca. $3 \mathrm{~m}$. Unlike its attached wall and the 18th century rampart remains at the French hospital, this tower was not built on relief arches but on eight courses of rough but solid stone foundations. Six courses of well-cut ashlars were exposed as part of the tower superstructure. During the late 19th century, the wall and tower were reused as the base of a new wall separating
Jaffa's Mahmudi mosque and the new military compound.

A third segment of the 18th century wall was discovered in 2010 at Ruslan Street (Arbel, Hater and Yechielov 2012). The street is adjacent to the Ottoman military compound, and the wall found there is an extension of the above-mentioned wall attached to the semicircular tower. Eight courses of well-cut ashlars were preserved over foundation courses that included relief arches. The preserved height reaches over $2.5 \mathrm{~m}$. One of the Jacotain maps shows a secondary trail leading roughly to this location and possibly linking to an entryway built into the wall. A concentration of human bones was discovered next to the foundations of the wall. The identity of the dead and the circumstances of their disposal in this location remain unclear. The proposal that this may have been a mass grave of victims of the violent French takeover, during which thousands of the defenders and the civilian population of Jaffa were massacred, remains unproven.

\section{The reconstructed fortifications}

The British Engineering Corps maps. Two maps of Jaffa were prepared by officers of the British Engineering Corps in 1841 and 1842. The maps present Jaffa's restored fortifications following the French withdrawal, bathymetric features of the port, and for the first time, basic features within the city (Jones 1973:40; Goren 


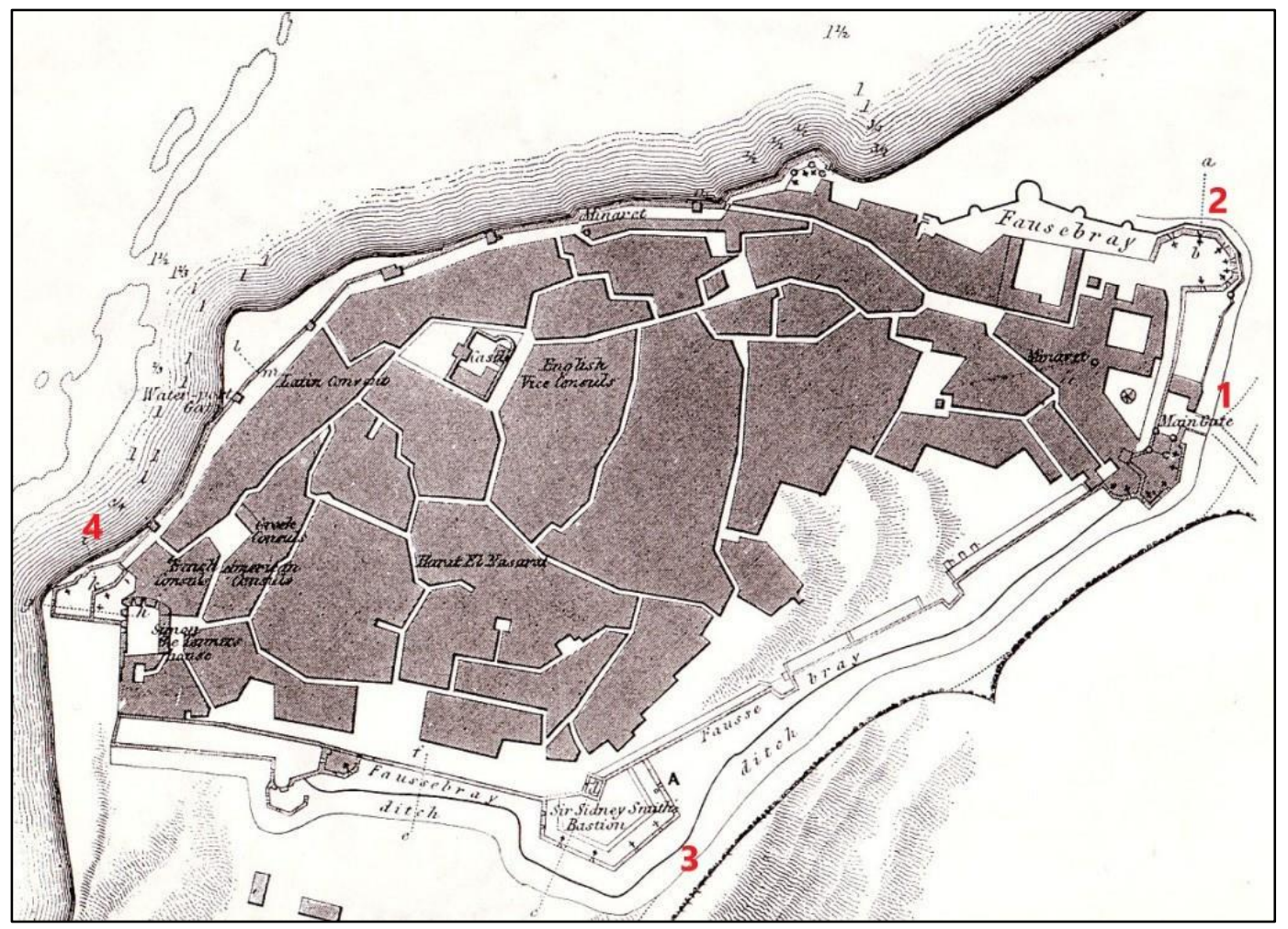

Figure 5. The walled town in Skyring's map of the region of Jaffa. Source: Alderson 1843.

2002; Shacham 2011: figs. 13.12-13). The 1841 map was drawn by Major Frederick H. Robe, and attached to a report by Lieutenant-Colonel R.C. Alderson and Lieutenant C.F. Skyring on Jaffa's walls and possible improvements. This is the only source that shows four secondary gates in the northern walls. The northeastern gate is located roughly at the spot of the gate exposed at Ruslan Street (see Figure 5, above), yet the Ruslan Street remains seem related to the 18th century wall of the Ottoman military compound. This gate, like other parts of the 18th century walls, may have been incorporated in the restored fortifications of the early 19th century and later sealed in. Conspicuous structural additions to the ramparts, such as the bastions at the northeastern and southeastern corners of the walls first appear in this map. Lieutenant Skyring's map from 1842 (Figure 5) is more detailed. The bastions and main gate at the eastern wall are rendered with greater precision and several cross sections of the fortifications have been added. Orange groves, cemeteries and a large "Hospital for Turkish troops" - soon to be Jaffa's quarantine station - are marked outside the walls, as are roads leading south, southeast and northeast. Inside Jaffa, the map shows the main streets crossing the city, mosques, convents and the residences of consular officials. Jaffa's citadel is placed approximately near to the present-day St. Peter Monastery in Jaffa's Old City. Of particular note is the empty lot in the southeastern area within the city walls.

Archaeological evidence. Remains corresponding to the Skyring map include parts of Jaffa's main city gate, of the northeastern and southeastern bastions and of the seawall by the port (Figures 5.1-4 respectively). Jaffa's eastern gate, known as the Jerusalem or Abu Nabbut
Gate, is shown in exceptional quality in a photograph by Louis Vignes from 1860 (Shacham 2017) and another by Félix Bonfils from 1878. Key elements of this gate were discovered in archaeological excavations in 2011 (Arbel and Rauchberger 2017:167-172). The 18th century maps also show a gate at the same location, but the 19 th century complex depict what appears to be a far more elaborate plan.

The gate complex was accessed via a bridge across a moat. Excavations revealed that the bridge was erected over two strong arches and, at least in its final stage, paved with flagstones. Two low bastions protected the bridge. They were built of well-dressed stones solidified with mortar and topped with white-plastered parapets. Part of the northern bastion was exposed in the excavations. Numerous Ottoman coins and many sherds of local clay vessels and of European faience bowls were found in the soil with which the moat was sealed when the ramparts were dismantled in the late 19th century.

Having crossed the bridge, incomers reached an enclosed and shaded courtyard. On its north side was an ornate, triple-spout fountain (sabil), which has survived intact to this day (Kana'an 2001b). A wall approximately six $\mathrm{m}$ tall, on the west side of the courtyard, blocked direct access to the city. The fountain's drain system and the foundations of the wall were exposed in the excavations. The entry gate was to the south, under a low tower with rounded corners. Parts of the tower were incorporated in later construction and can still be seen. The gate complex occupies only a fraction of Skyring's map, but is represented in detail, and each of the 


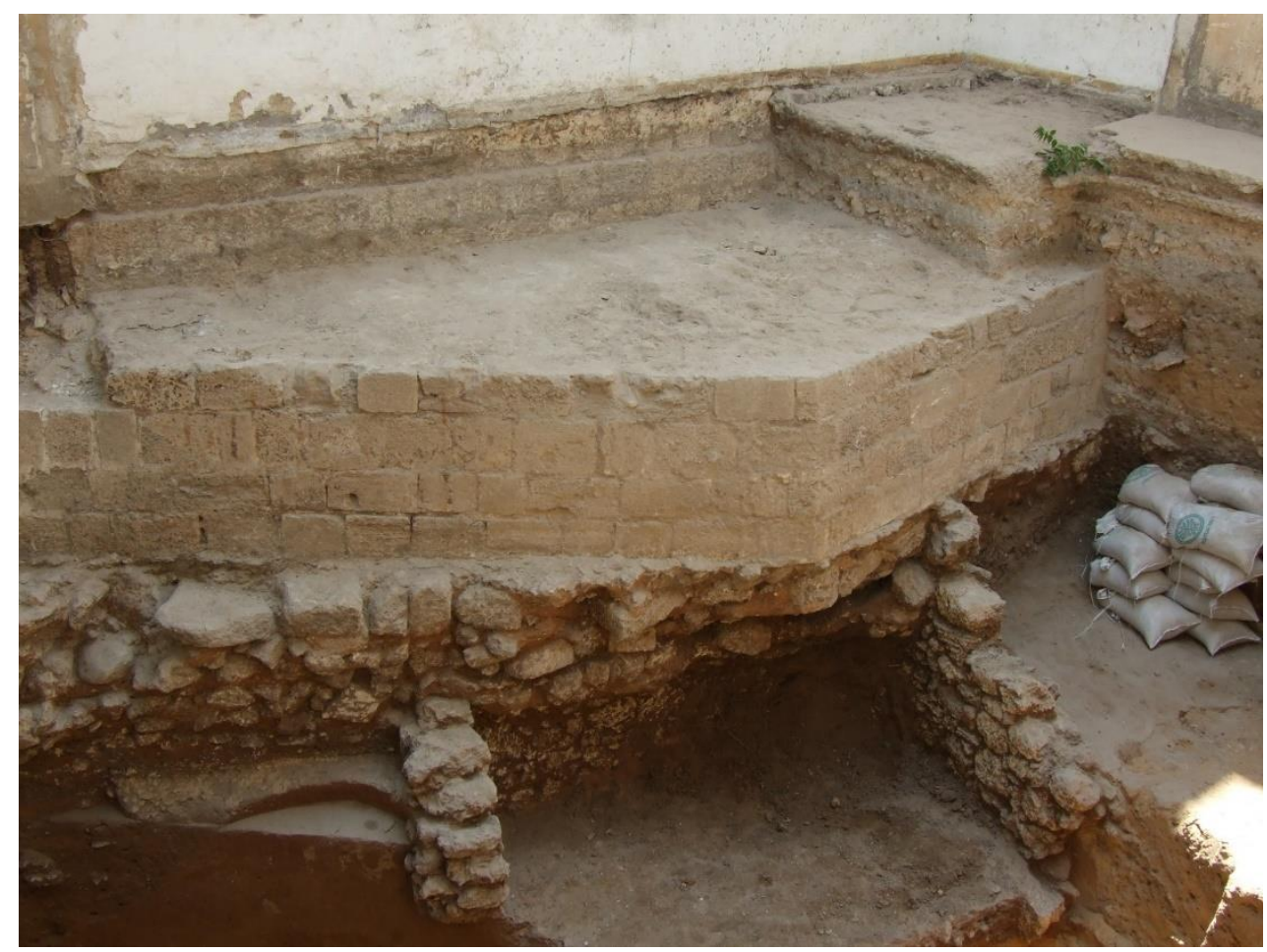

Figure 6. Corner of the 19th century hexagonal bastion and earlier room underneath. Photograph by T. Sagiv, Israel Antiquities Authority.

photographed and excavated elements may be traced on it.

A short distance from the gate stood the northeastern bastion of Jaffa's fortifications. The relatively low yet strategically-placed hexagonal structure is shown on both British maps and depicted on a panorama by J.M.W. Turner from 1837 (Ze'evi 1985:76). A corner of the bastion was exposed in excavations at the Ottoman military compound (Arbel, in press). It consists of five courses of mortar-bonded ashlars reaching $1.30 \mathrm{~m}$ in height and set over a rough foundation (Figure 6). Within the remains of an 18th century room found under the foundations was a large number of human bones, some in partial articulation. The remains may belong to victims of the Napoleonic conquest or to deceased, whose tombs were disturbed when the bastion was built. Considerable remains of Jaffa's largest bastion at the southeastern corner of the walls (named after Sir Sidney Smith) were exposed at the St Louis Hospital site (Re'em 2010), along with part of the city wall (for testimonies to its establishment ceremony see Wittman 1803:142-143; The Sporting Magazine, October 1800, pp. 180-181). Excavations indicate that it was a doublestory pentagonal structure, with an outer wall $2.5 \mathrm{~m}$ thick, and a $1.5 \mathrm{~m}$ thick inner wall enclosing a courtyard, where a forge for the production of cannon balls operated. Part of the outer wall (up to $3 \mathrm{~m}$ high) was incorporated in the perimeter fence of the later hospital. Troops and cannons could be positioned between the walls. An exposed strip for the trapping of attackers (fausse-braye) was left between the outer wall and the moat. All these features are consistent with the detailed depiction of the complex on the Skyring map.
Archaeological remains related to features on the Skyring map were also found at the port, namely, a stone wall along the waterfront and the foundations of a small fortress (Haddad 2009). The wall was part of Jaffa's seawall, constructed in the early 19th century and preserved, as historical photographs show, until as late as 1875 . The superstructure courses were set over a foundation of larger and coarser stones. Some of the superstructure ashlars have drafted margins, indicating the secondary use of Crusader blocks in the Ottoman construction. Various sources attest to the extraction of building stones and architectural elements from the ancient Roman and Crusader harbors of Ascalon and Caesarea (Kark 1990:19; Haddad 2013:90). Excavated segments of the wall were preserved to a height of approximately $2 \mathrm{~m}$ above the waterline. The trapezoid fortress (approximately $20 \times 30 \mathrm{~m}$ ), depicted on both British maps, was exposed in the southern part of the harbor. On the 1841 map it is named "Simon Peter's bastion", after the nearby building traditionally identified as the house of Simon the Tanner, Peter's host during his prolonged stay in Jaffa (Acts 9:43). Its inner space was stone-paved and situated on an underground vault with possible Crusader origins.

\section{A developing city}

The Bedford map. In 1863 British Lieutenant F.D.G. Bedford prepared a new map of Jaffa. Although it is a bathymetric map, part of a general survey of the coast of the Holy Land (Rosen 1992; Shacham 2011:139; Haddad 2013:135-138), this was the first map to include a draft plan of the streets and blocks of buildings within the walls. There was clearly no claim to accuracy, but a few points stand out. First, in the twenty years that had 


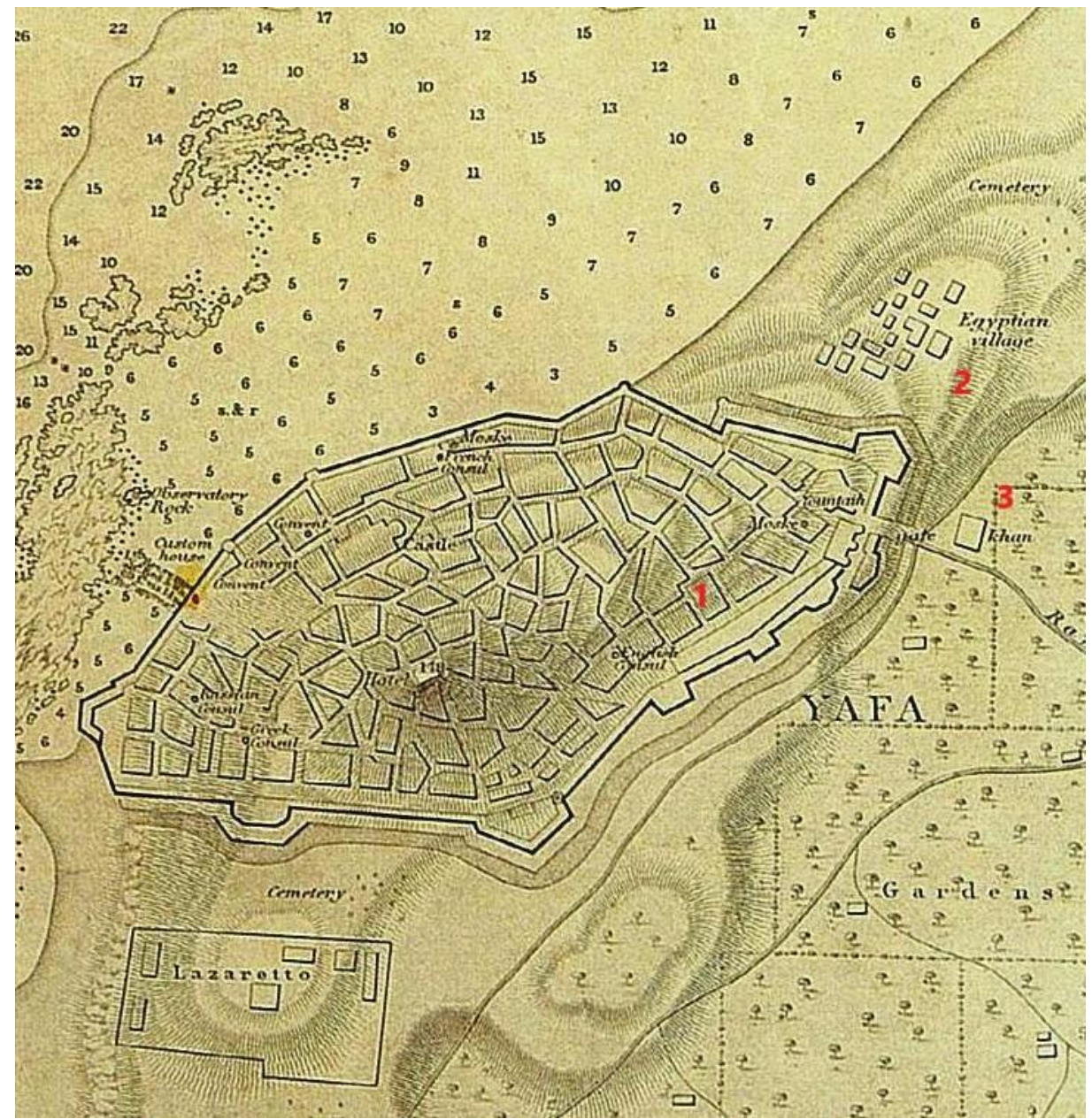

Figure 7. Bedford's map of Jaffa Lieutenant Bedford's map of Jaffa. The Baruch Rosen Collection

elapsed since Skyring's map the southeastern part of Jaffa had been completely filled with construction (Figure 7.1). Second, the city wall line still appeared along its full course. Third, the new outer settlements that Ibrahim Pasha had founded in the 1830s for immigrant Egyptian peasants made their first cartographic appearance (Figure 7.2). Lastly, traveler hostels (khans) appeared outside the walls (Figure 7.3), harbingers of Jaffa's extra-mural expansion that was to gather momentum in the following decades. In many ways, the Bedford map offers the first solid cartographic testimony to the processes behind the development of modern Jaffa.

Archaeological evidence. Excavations at HaZorfim Street during 2008-2009 revealed supporting evidence for the new construction in the southeastern part of the walled city (Arbel 2010). The street, which appears on the Bedford map, generally preserves its 19th century delineation (Figure 8). The foundations of large doublestory houses, segments of stone-paved streets and a multi-channel drain system came to light along its course. The homes belonged to Jaffa's wealthier residents. By exploiting free plots away from the rest of the city, which was a crowded, organically-evolved labyrinth, they could benefit from modern infrastructure
(Kark 1981:105-106), and far healthier and more comfortable conditions for their families.

The "Egyptian village" marked on the Bedford map (Figure 7.2) was one of several such settlements founded in the close and farther peripheries of Jaffa. Most of these settlements steadily grew during the 19th century. As Jaffa ventured out of its walls, they developed into fully-fledged urban suburbs. The village marked on the Bedford map would later become the Manshi'a neighborhood. A similar development took place to the south of Jaffa's hill, as the original settlement there evolved into the neighborhoods of Huraish and 'Ajami (Figure 9). The various communal cemeteries outside the city attest to the demographic growth of Jaffa and its heterogeneous population during this period. The main Muslim cemetery was to the north of the walls, while the only Jewish cemetery and the graveyards of various Christian denominations were established to the south of the walls (Kark 1981:104).

\section{Post-ramparts expansion}

The Sandel map. Architect Theodor Sandel, a resident of Jaffa's German Colony and a member of the Templer community, is responsible for several maps of Jaffa and its environs. One of his works, from 1878, offers the most detailed map of the city proper up to that time (Figure 10). Sixty-four public institutions and homes of 


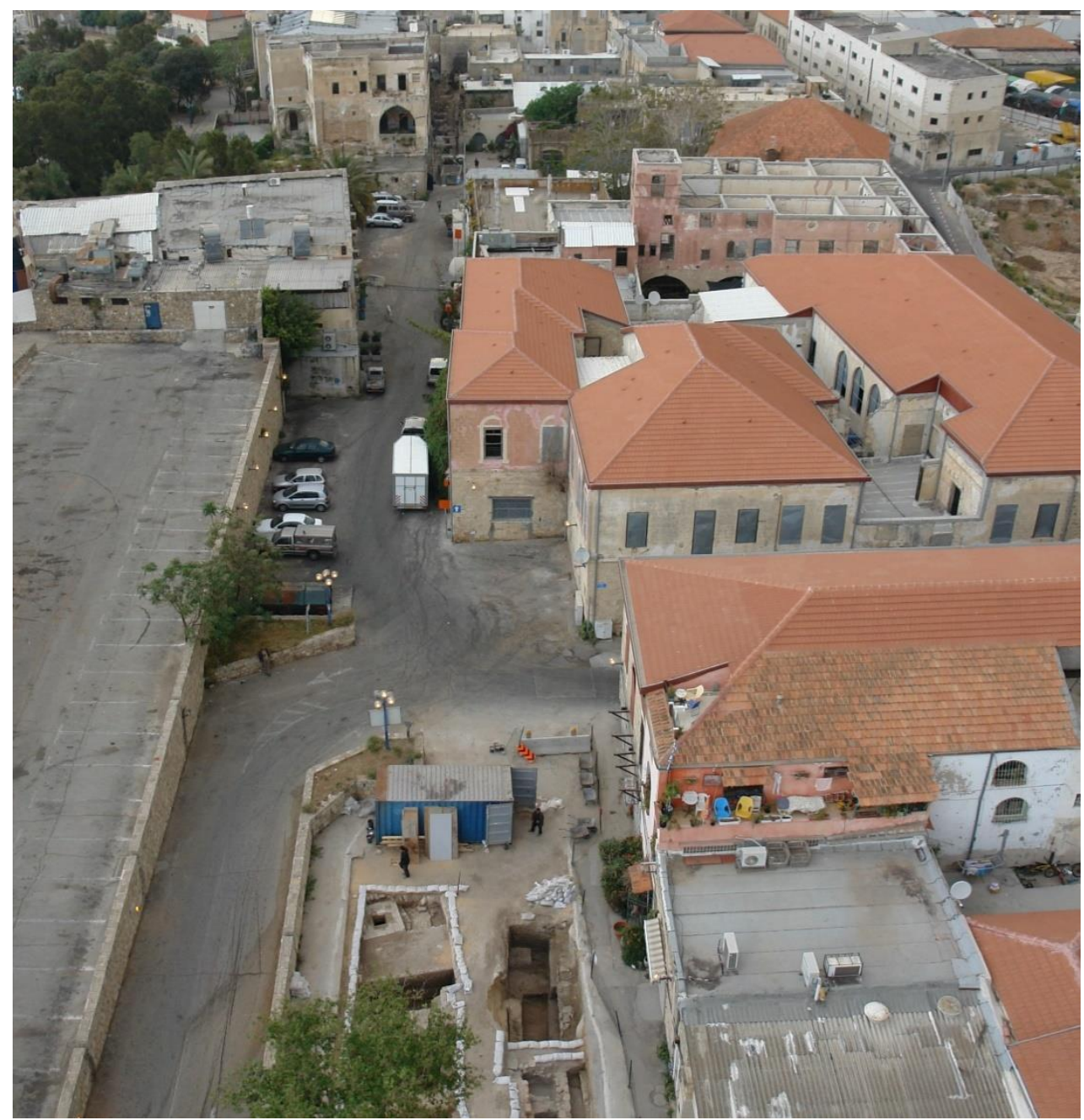

Figure 8. The southern part of HaZorfim Street with late 19th century houses built over the line of the eastern fortifications. Photograph by Skyview, courtesy of the Israel Antiquities Authority.

leading figures are numbered on the map (Shacham 2011:139-140; Kark 1990:64-65). Unlike the three previous maps discussed here, this was a civilian map, concerned with the town rather than its defenses.

Two key aspects of Jaffa's development in the late 19th century are evident. The first is the almost complete disappearance of the fortifications. The ramparts, built in the early 19th century, would not have been able to sustain the impact of modern artillery, and by then Bedouin attacks and peasant insurrections were no longer a concern. Furthermore, in their ineffectualness, Jaffa's fortifications had now lost the historical, crosscultural symbolic value of city walls as a materialization of the power of the city and its government (DeMarrais, Castillo and Earle 1996:18-19; Ilan 1998:314). At the same time, the walls had become an impediment to expansion into new grounds in the city's immediate periphery. Constantinople issued the royal decree (firman) for their removal in 1888, but by then much had already been dismantled. The gate complex and the northeastern bastion still appear on the Sandel map. The bastion is named the old fort (Alt Fort), hinting at its defensive irrelevance at the time. The moat was filled in and new buildings were constructed along the ramparts line, using stones taken from the wall. A large customs house and a wharf were built at the port over the defunct sea wall and fortress, shown in a photograph from the period in a state of dereliction (Haddad 2013: 144-145). By that time, commercial activity in the port was booming, yet there seemed no need to maintain its old defenses. Plans for the building of a new harbor, which never materialized, were mostly focused on facilitating the flow of people and merchandise to and from the city and the railway station linking Jaffa and Jerusalem, which was established in 1892 (Mirkin 2017:144-151). The second development was the intensification of construction outside the formerly walled city. The Bedford map places a single khan at the Jaffa end of the Jerusalem road. The Sandel map, reflecting the situation only fifteen years later, shows new buildings - most of which presumably had hosting and commercial functions - along both sides of the road and to a lesser extent along the roads running northeast and south. An open market for agricultural products (Gemüse und Früchte Markt) appears in the grounds between the city gate and the northeastern bastion, with buildings on both sides. Two decades later a new urban square would stand on that site, graced with a clock tower and 


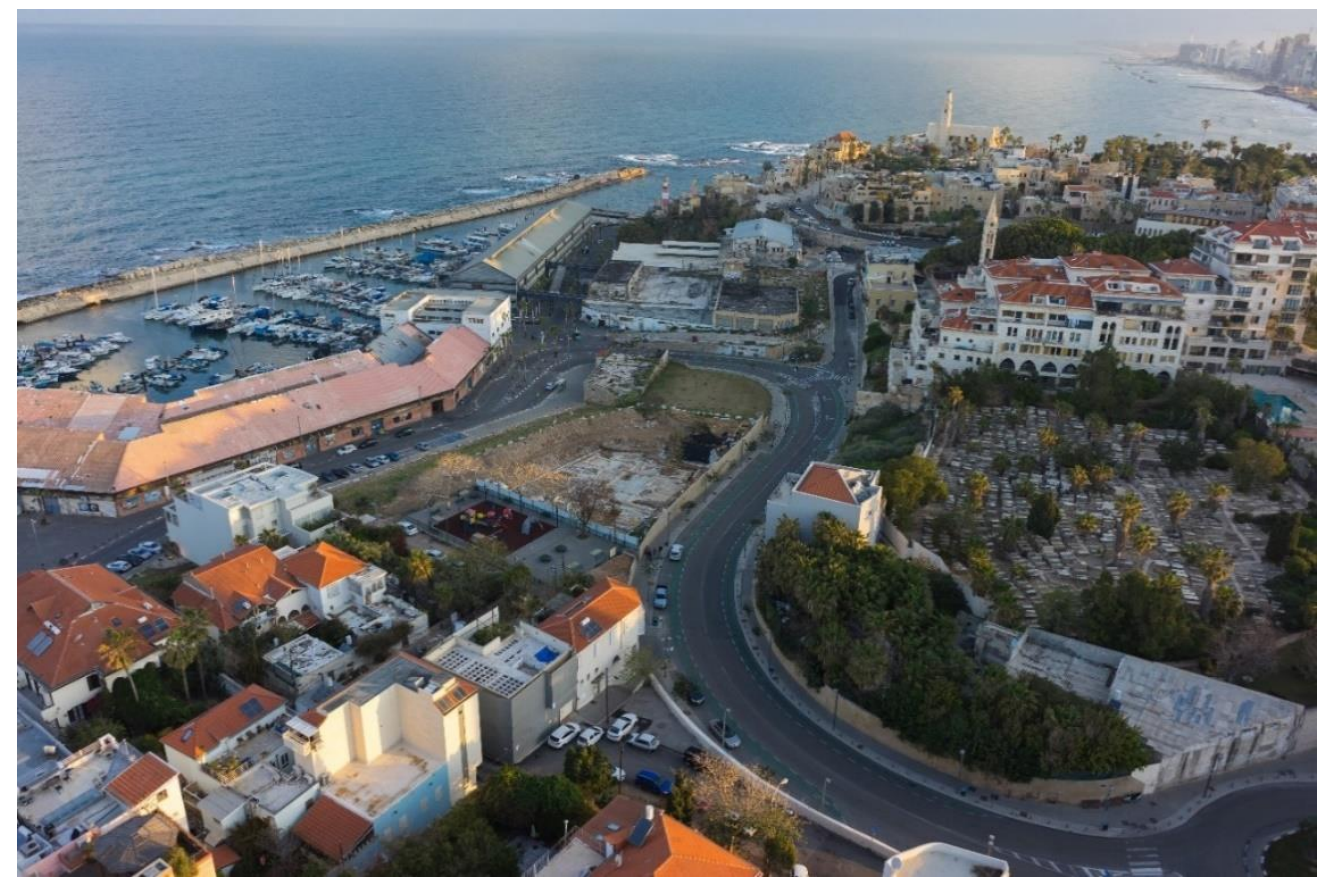

Figure 9. The Jaffa hill from the south. To the left, the 'Ajami neighborhood that began as one of the Egyptian settlements on Jaffa's immediate periphery. To the right, the old Jewish cemetery. Photograph by the Griffin Company, courtesy of the Israel Antiquities Authority.

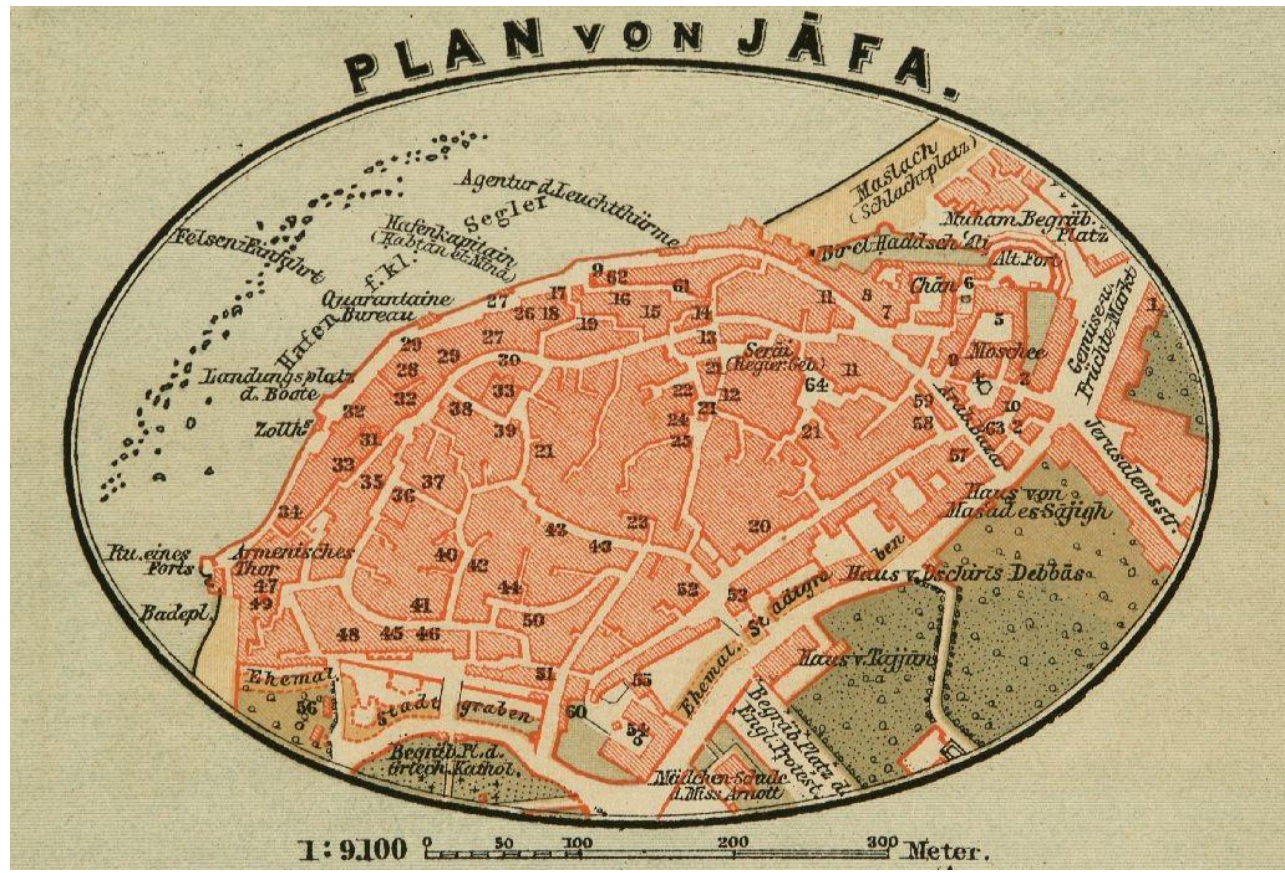

Figure 10. Sandel's map of Jaffa in 1878. Source: Schwartz 1880, T. Shacham collection.

surrounded by government and religious institutions (Giler 2019:47-51). Thus, the Sandel map reflects the early stage of settlement in the eastern areas, which was to alter Jaffa's appearance and urban character in the next decades.

Archaeological evidence. The wave of construction came at the expense of Jaffa's agricultural fields and famous orchards. On the Sandel map they still occupy the grounds between the eastern and northeastern roads, but during the 1890 s a commercial district would be built there by the Greek Orthodox Church (Kark 1990:261; Arbel 2016). This example reflects a far broader phenomenon. The twilight years of Ottoman rule and the three subsequent decades of British Mandate saw other housing and commercial construction covering the former farmland. Material evidence of this dramatic transformation includes wells, well houses (complexes for the drawing, storing and distribution of water) and irrigation ducts exposed under many streets and buildings that date from the turn of the 


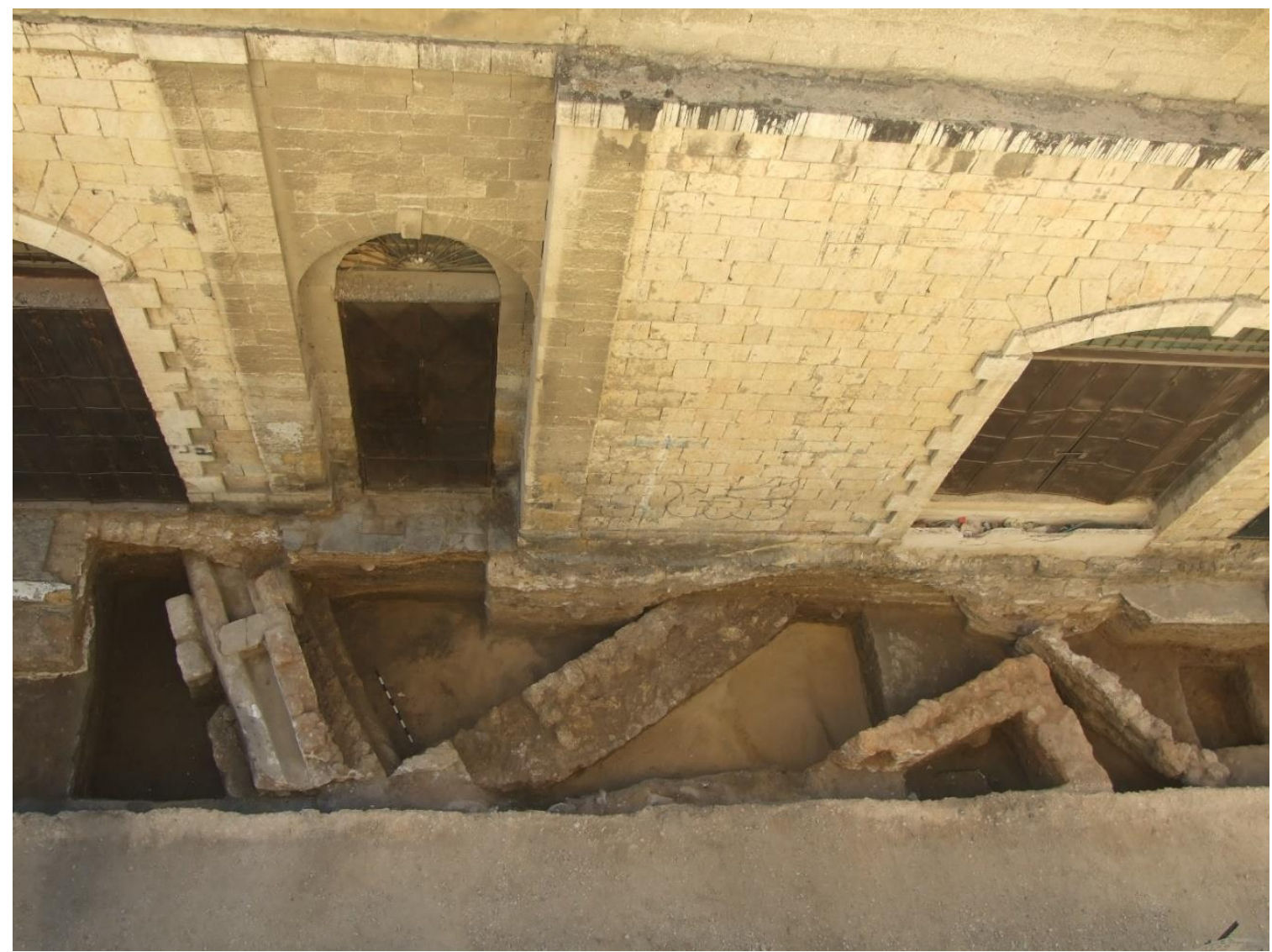

Figure 11. Irrigation channel (left) and farming-related structures (right) under a street and building in the Greek Market. The wall in between remains from a Crusader structure. Photograph by the author.

20th century (Gorzalczany 2008; Rauchberger 2015; Arbel and Rauchberger 2020:256-263) (Figure 11). While archaeological exposure within an extant city is restricted, excavations carried out in open sites have revealed irrigation channels extending for dozens of meters, with terracotta pipes embedded in intersections for water regulation (Golan 2015). Many well houses later evolved into pleasant and even luxurious residences for Jaffa's wealthy landowners. Some of the Ottoman-era well houses disappeared with urbanization, but others were incorporated into new construction and may still be detected in modern Jaffa and its broader periphery, now the crowded and bustling streets and alleys of south-central Tel Aviv (Sasson and AmitaiPreiss 2017; Sasson 2009).

\section{Conclusions}

In his The Innocents Abroad, American author Mark Twain shares his experiences during his visit to the Holy Land in 1867. Although often humorous, his text is beset with disillusion. "For Twain," notes H. Obenzinger (1999:178), "the Holy Land has become nothing but Palestine, a small, impoverished province of Syria...disappointing, dead [and] resurrected only in the imagination by the effects of distancing and memory or through nature's theatricality." Twain was not alone in his disenchantment with the Holy Land under Ottoman rule; relentless criticism is rife in memoirs of the period.
Jaffa, being the gateway to the fabled land and home to biblical fables of its own, sustained an ample portion of unflattering narratives. The men and women who wrote them occasionally exaggerated, but they did not lie. Still, they lacked the broader perspective and the impartiality (even if relative) of later research. Perspective and impartiality are two of the better instruments by which concepts are distinguished from facts. Cartography and archaeology are based on precisely such instruments.

Efforts to map cities of the Holy Land did not begin with Pierre Jacotain. Bernhard von Breidenbach, with his Peregrinatio in terram sanctam of the late 15th century, and others made their own attempts before him, albeit in more schematic and artistic forms. At the other end of the scale, numerous later maps followed in Theodor Sandel's steps (Haddad 2013:75-76; Shacham 2011:140-141, figs.13.20-35). The 19th century, nonetheless, was a turning point, with military and civilian maps depicting various phases in Jaffa's development in increasing detail and with a broadening sphere of interest. In that sense, the maps discussed in this article, along with others from the same time span, mark the genesis of Jaffa's scientific cartography.

Archaeological excavations in sites of the recent past often uncover the foundations of buildings already familiar from textual and cartographic sources. Although the buildings are known, the excavations may 
add indispensable background information about their historical, cultural and economic settings. In some cases, furthermore, they reveal elements that map-makers miss, ignore or misrepresent. Archaeology is thus not a supporting discipline to historical cartography, just as it is not a service provider on behalf of historians. As this article strives to show, archaeology and historical cartography play complementary roles. Present and future investigations of Jaffa during the 19th and even the early 20th centuries would never be complete if authors were to ignore either one of them, or most importantly, the combined contribution of both.

\section{References}

Alderson, R.C. (1843). Notes on Acre and Some of the Coast Defences of Syria. Papers on Subjects Connected with the Duties of the Corps of Royal Engineers 6 (1844). London, pp. 19-62.

Arbel, Y. (2010). Yafo, HaZorfim Street, Preliminary Report. Excavations and Surveys in Israel 122.

http://www.hadashot-

esi.org.il/report detail eng.aspx?id=1474\&mag $\mathrm{id}=11$ 7 .

Arbel, Y. (2014). The Archaeology of Urban Change: 19th century Jaffa. In: Bovati, M., Caja M., Floridi, G. and Landsberger, M. (eds) Cities in Transformation: Research \& Design. EAAE Transaction on Architectural Education no 57, Politecnico di Milano, pp. 531-538.

Arbel, Y. (2016). Yafo, the Greek Market, Preliminary Report. Excavations and Surveys in Israel 128.

http://www.hadashot-

esi.org.il/report detail eng.aspx?id=25112\&mag $\mathrm{id}=1$ 24.

Arbel, Y. (2017a). Ottoman Jaffa: from Pilgrim's Anchorage to Regional Center. In: Plosnić Škarić, A. (ed) Mapping Urban Changes. Institute of Art History, Zagreb, Croatia, pp. 392-413.

Arbel, Y. (2017b). Salvage Excavations in Jaffa's Lower Town, 1994-2014. In: Burke, A.A., Burke, K.S. and Peilstöcker, M. (eds) The History and Archaeology of Jaffa II. Cotsen Institute of Archaeology Press, Los Angeles, pp. 63-88.

Arbel, Y. (2017c). Post-Medieval Muslim Burials in Jaffa: Archaeological Evidence and Historical Perspective. Journal of Islamic Archaeology 4.1:87112.

Arbel, Y. (in press). The Stratigraphy. In: Arbel Y (ed) Excavations at the Ottoman Military Compound (Qishle) in Jaffa. The History and Archaeology of Jaffa IV. Ugarit Verlag, Münster, Germany.

Arbel, Y., Hater, M. and Yechielov, S. (2012). Yafo, Roslan and Mifraz Shlomo Streets. Excavations and Surveys in Israel 124.

http://www.hadashot-

esi.org.i1/report_detail_eng.aspx?id=2117\&mag_id=11 9.

Arbel, Y. and Rauchberger, L. (2017). The Jerusalem Gate of Late Ottoman Jaffa: An Updated Survey. In:
Burke, A.A., Burke, K.S. and Peilstöcker, M. (eds) The History and Archaeology of Jaffa II. Cotsen Institute of Archaeology Press, Los Angeles, pp. 163-178.

Arbel, Y. and Rauchberger, L. (2020). Remains from the Hellenistic through the Late Ottoman-British Mandate Periods in the Magen Avraham Compound, Yafo (Jaffa). 'Atiqot 100:245-277.

Blumberg, A. (2007). Zion before Zionism, 1838-1880. Devora, Jerusalem.

DeMarrais, E., Castillo, L.J. and Earle, T. (1996). Ideology, Materialization and Power Strategies. Current Anthropology 37.1:15-31.

Dénain, J. (1830-36). Histoire scientifique et militaire de l'expédition française en Egypte. Paris.

Giler, S. (2019). From a Fellaheen Market to the City Square: The Development of the Clocktower Square in Jaffa. In: Shiller, E. (ed) The Unknown Jaffa. Ariel 217, pp. 45-56 (Hebrew).

Glick, A., Stone, M.E. and Terian, A. (2014). An Armenian inscription from Jaffa. Israel Exploration Journal 64.1:103-118.

Golan, D. (2015). Nes Ziyyona, Sarafand el-Kharab. Excavations and Surveys in Israel 127.

http://www.hadashot-

esi.org.i1/report_detail_eng.aspx?id=15734\&mag_id=1 22.

Goren, H. (2002). Sacred but not Surveyed. Nineteenthcentury Surveys of Palestine. Imago Mundi 54:87-110. Gorzalczany, A. (2008). Yafo. Excavations and Surveys in Israel 120.

http://www.hadashot-

esi.org.il/report detail eng.aspx?id=888\&mag id=114. Haddad, E. (2009). Yafo Harbor, preliminary report. Excavations and Surveys in Israel 121.

http://www.hadashot-

esi.org.il/report detail eng.aspx?id=1184\&mag $\mathrm{id}=11$ $\underline{5}$.

Haddad, E. (2013). The Ascendance and Decline of the Jaffa Sea Port from the Time of the Crusaders Period to the Beginning of the First World War. Unpublished PhD. Diss. University of Haifa (Hebrew).

Ilan, D. (1998). The Dawn of Internationalism - the Middle Bronze Age. In: Levy, T.E. (ed) The Archaeology of Society in the Holy Land. Leicester University Press, London, pp. 297-319.

Jones, Y. (1973). British Military Surveys of Palestine and Syria 1840-1841. Cartographic Journal 10 (1):2941.

Kana'an, R. (2001a). Waqf, Architecture, and Political Self-fashioning. The Construction of the Great Mosque of Jaffa by Muhammad Aga Abu Nabbut. Muqarnas 18:120-140.

Kana'an, R. (2001b). Two Ottoman Sabils in Jaffa (c. 1810-1815): an Architectural and Epigraphic Analysis. Levant 33:189-204.

Kaplan, J. (1972). The Archaeology and History of Tel Aviv-Jaffa. The Biblical Archaeologist 35.3:65-95. Kark, R. (1981). The Traditional Middle Eastern City: the Cases of Jerusalem and Jaffa. Zeitschrift des Deutschen Palästina-Vereins 97:93-108. 
Kark, R. (1990). Jaffa, a City in Evolution (1799-1917). Yad Izhak Ben-Zvi, Jerusalem.

Kark, R. (2011). Ottoman Jaffa: from Ruin to Central City in Palestine. In: Peilstöcker, M. and Burke, A.A. (eds) The History and Archaeology of Jaffa I. Cotsen Institute of Archaeology Press, Los Angeles, pp. 129-136. Mirkin, D. (2017). The Ottoman Port of Jaffa: A Port Without a Harbor. In: In: Burke, A.A., Burke, K.S. and Peilstöcker, M. (eds) The History and Archaeology of Jaffa II. Cotsen Institute of Archaeology Press, Los Angeles, pp. 121-155.

Murray, J. (1858). Handbook for Travelers in Syria and Palestine. London.

Obenzinger, H. (1999). American Palestine; Melville, Twain and the Holy Land Mania. Princeton University Press, Princeton, New Jersey.

Rauchberger, L. (2015). Yafo, the Postal Compound. Excavations and Surveys in Israel 127. http://www.hadashot-

esi.org.il/report detail eng.aspx?id=20764\&mag id=1 $\underline{22}$.

Re'em, A. (2010). Yafo, the French Hospital, 20072008. Preliminary Report. Excavations and Surveys in Israel 122.

http://www.hadashot-esi.org.il/re-

port detail eng.aspx?id=1566\&mag id $=117$.

Rosen, B. (1992). Survey of the Coast of Palestine by the Royal Navy. Cathedra 64:59-78 (Hebrew, English summary p. 183).

Sasson, A. (2009). Wells and Orchards in Jaffa and its Environs. In: Tzur, M. and Rothbard, S. (eds) Neither in Jaffa nor Tel Aviv. Bavel and Bina, Tel Aviv, pp. 59-69 (Hebrew).
Sasson, A. and Amitai-Preiss, N. (2017). The Blessed Bayāra: a Bayāra and Arabic Inscription from Late Ottoman Jaffa. In: Burke, A.A., Burke, K.S. and Peilstöcker, M. (eds) The History and Archaeology of Jaffa II. Cotsen Institute of Archaeology Press, Los Angeles, pp. 199-214.

Schwartz, G. (1880). Jaffa und Umgebung. Zeitschrift des Deutschen Palästina-Vereins III: 44-51; Tafel III.

Shacham, T. (2011). Jaffa in Historical Maps. In: Peilstöcker, M., and Burke, A.A. (eds) The History and Archaeology of Jaffa I. Cotsen Institute of Archaeology Press, Los Angeles, pp. 137-174.

Shacham, T. (2017). A Panoramic View of Late Ottoman Jaffa from November 1860 by Louis Vignes. In: Burke, A.A., Burke, K.S. and Peilstöcker, M. (eds) The History and Archaeology of Jaffa II. Cotsen Institute of Archaeology Press, Los Angeles, pp. 157162.

Shacham, T. (in press). The Northeastern Bastion of Jaffa's Fortifications. In: Arbel, Y. (ed) Excavations at the Ottoman Military Compound (Qishle) in Jaffa. The History and Archaeology of Jaffa IV. Ugarit Verlag, Münster.

Tolkowsky, S. (1924). The Gateway of Palestine. George Routledge \& Sons, London.

Volney, C.F. de (1778). Travels through Syria and Egypt in the Years 1783, 1784 and 1785. J. Robinson, London.

Wittman, W. (1803). Travels in Turkey, Asia-Minor, Syria and Across the Desert into Egypt, During the Years 1799, 1800, 1801. T. Gillet, London.

Ze'evi, R. (ed) (1985). Yafo - Tides of Times. Ha'aretz Museum, Tel Aviv (Hebrew). 